\title{
RhoA GTPase inactivation by statins induces osteosarcoma cell apoptosis by inhibiting p42/p44- MAPKs-Bcl-2 signaling independently of BMP-2 and cell differentiation
}

\author{
O Fromigué ${ }^{1}$, E Haÿ ${ }^{1}$, D Modrowski ${ }^{1}$, S Bouvet ${ }^{1}$, A Jacquel ${ }^{2}$, \\ P Auberger ${ }^{2}$ and PJ Marie ${ }^{*, 1}$ \\ 1 INSERM U606, University Paris 7, IFR 139, Lariboisière Hospital, 2 rue \\ Ambroise Paré, 75475 Paris Cedex 10, France \\ 2 INSERM U526, Faculty of Medicine Pasteur, Equipe labellisée LNC, IFR 50, \\ Nice, France \\ * Corresponding author: PJ Marie, INSERM Unit 606, Hôpital Lariboisière, 2 rue \\ Ambroise Paré, 75475 Paris cedex 10, France. Tel: +33-1-49-95-63-89; \\ Fax: + 33-1-49-95-84-52; E-mail: pierre.marie@larib.inserm.fr
}

Received 29.8.05; revised 20.12.05; accepted 20.12.05; published online 10.2.06 Edited by SH Kaufmann

\begin{abstract}
Osteosarcoma is the most common primary bone tumour in young adults. Despite improved prognosis, resistance to chemotherapy remains responsible for failure of osteosarcoma treatment. The identification of signals that promote apoptosis may provide clues to develop new therapeutic strategies for chemoresistant osteosarcoma. Here, we show that lipophilic statins (atorvastatin, simvastatin, cerivastatin) markedly induce caspases-dependent apoptosis in various human osteosarcoma cells, independently of bone morphogenetic protein (BMP)-2 signaling and cell differentiation. Although statins increased BMP-2 expression, the proapoptotic effect of statins was not prevented by the BMP antagonist noggin, and was abolished by mevalonate and geranylgeranylpyrophosphate, suggesting the involvement of defective protein geranylgeranylation. Consistently, lipophilic statins induced membrane RhoA relocalization to the cytosol and inhibited RhoA activity, which resulted in decreased phospho-p42/p44- mitogen-activated protein kinases (MAPKs) and Bcl-2 levels. Constitutively active RhoA rescued phospho-p42/p44-MAPKs and Bcl-2 and abolished statininduced apoptosis. Thus, lipophilic statins induce caspasedependent osteosarcoma cell apoptosis by a RhoA-p42/p44 MAPKs-Bcl-2-mediated mechanism, independently of BMP-2 signaling and cell differentiation.

Cell Death and Differentiation (2006) 13, 1845-1856.

doi:10.1038/sj.cdd.4401873; published online 10 February 2006
\end{abstract}

Keywords: apoptosis; osteosarcoma; statins; RhoA; MAPKs

Abbreviations: Ac-DEVD-pNA, acetyl-Asp-Glu-Val-Asp-paranitroaniline; BMP, bone morphogenetic protein; BMPR-IB, BMP receptor IB; BSA, bovin serum albumin; $C A$, constitutively active form; FCS, fetal calf serum; FPP, farnesylpyrophosphate; GAPDH, glyceraldehyde 3-phosphate deshydrogenase; GGPP, geranylgeranylpyrophosphate; HMG-CoA, 3-hydroxy 3-methylglutaryl coenzyme A; MAPKs, mitogen-activated protein kinases; $\mathrm{PI} 3 \mathrm{~K}$, phosphoinositide $3^{\prime}$ kinase; NO, nitric oxide; RT-PCR, reverse transcription-polymerase chain reaction; TBST, tris hydroxymethylaminomethane buffered saline Tween-20; WT, wild-type form; zVAD-fmk, z-Val-Ala-Asp-fluoromethylketone

\section{Introduction}

Osteosarcoma is the most common primary malignant bone tumour occuring in children and young adults. Although aggressive chemotherapy has improved the prognosis of osteosarcoma patients, resistance to chemotherapy remains a major mechanism responsible for the failure of osteosarcoma treatment. ${ }^{1}$ Several studies have established that apoptotic pathways contribute to the cytotoxic action of chemotherapeutic drugs. ${ }^{2,3}$ Thus, combinational therapy with agents that promote the apoptotic machinary may be of potential interest to enhance apoptosis sensitivity and improve tumour burden. ${ }^{3,4}$

The cholesterol-lowering agents statins were recently found to trigger cell death in a variety of soft tumour cells. ${ }^{5,6}$ Statins inhibit the 3-hydroxy-3-methylglutaryl-coenzyme A (HMG CoA) reductase which catalyses the conversion of HMGCoA into mevalonate during the biosynthesis of cholesterol. Mevalonate can be converted into farnesylpyrophosphate (FPP) and geranylgeranylpyrophosphate (GGPP), two isoprenoid residues that can be anchored onto several intracellular proteins through farnesylation or geranylgeranylation, a process called prenylation. ${ }^{5,6}$ Protein prenylation is necessary for relocalization of target proteins to cell membranes, and is thereby involved in the control of cell adhesion, growth and survival. Blocking the mevalonate pathway by HMG-CoA reductase inhibitors inhibits geranylgeranylation and farnesylation, resulting in decreased prenylation of proteins and alteration of cell growth and survival functions. ${ }^{5}$ Small Gproteins, including the Ras, Rho and Rac families are signaling proteins that are dependent on prenylation for their localization to cell membranes and for their activity. ${ }^{7}$ Notably, RhoA has been implicated in the control of cell growth and apoptosis. ${ }^{7,8}$ Moreover, RhoA is overexpressed in several tumours, ${ }^{9}$ suggesting its possible implication in tumorigenesis. However, the contribution of RhoA in osteosarcoma cell survival and its downstream signaling proteins has not been determined.

The terminal differentiation of cells of the osteoblast lineage is directed by the integrated function of regulatory factors such as bone morphogenetic proteins (BMPs) and downstream transcription factors. BMP-2, a member of the TGF beta superfamily, and Runx2, a master transcription factor acting as BMP effector, are important regulatory signals required for 
osteoblast differentiation. ${ }^{10,11}$ Runx2 promotes the expression of phenotypic markers in postproliferative osteoblasts $^{11,12}$ and induces suppression of preosteoblastic cell proliferation, ${ }^{13,14}$ which contributes to promote osteoblast maturation. Osteosarcoma cells are often characterized by loss of differentiated phenotype with decreased expression of osteoblast markers. ${ }^{15}$ Consistently, osteoblast differentiation mediated by Runx2 and the cyclin-dependent kinase (Cdk) inhibitor p27 (Kip1) is disrupted in osteosarcoma cells. ${ }^{16}$ Additionally, the upregulation of Runx2 with cessation of cell growth observed in normal osteoblasts ${ }^{13}$ is not observed in osteosarcoma cells, ${ }^{14,17}$ indicating a role for Runx2 dysregulation in osteosarcoma cell proliferation and differentiation.

We previously showed that, besides promoting Runx2 and cell differentiation, BMP-2 induces caspase-dependent apoptosis in human osteosarcoma cells through activation of BMP receptor IB (BMPR-IB). ${ }^{18}$ Some statins are known to activate the BMP-2 promoter, ${ }^{19,20}$ resulting in increased Runx2 expression and osteoprogenitor cell commitment to osteoblasts. ${ }^{21}$ These studies raise the question of whether statins may promote apoptosis in osteosarcoma cells through induction of BMP-2. In this study, we provide evidence that lipophilic statins induce caspase-dependent apoptosis in human osteosarcoma cells independently of BMP-2 signaling and commitment to cell differentiation, by a mechanism specifically involving inactivation of RhoA and p42/p44 mitogen-activated protein kinases (MAPKs)-Bcl-2 survival pathway.

\section{Results}

\section{Lipophilic statins induce caspases-dependent apoptosis in human osteosarcoma cells}

We first investigated whether hydrophilic and lipophilic statins may induce apoptosis in human osteosarcoma cells cultured in growth supporting conditions (i.e. in the presence of $10 \%$ serum). As shown in Figure 1a, treatment with lipophilic statins (atorvastatin, cerivastatin, simvastatin) for $24 \mathrm{~h}$ decreased cell viability in human osteosarcoma cells expressing p53 $\left(\mathrm{OHS}_{4}\right)$ or not expressing p53 $\left(\mathrm{SaOS}_{2}\right)$. In contrast, the hydrophilic statin pravastatin did not affect cell viability. Consistent with these results, the lipophilic statins atorvastatin, cerivastatin and simvastatin induced a eight- to 10-fold increase in the number of TUNEL-positive cells, reflecting DNA fragmentation, with an optimal dose of $1 \mu \mathrm{M}$ for cerivastatin and $10 \mu \mathrm{M}$ for atorvastatin and simvastatin. In contrast, the hydrophilic statin pravastatin had no effect (Figure 1b). The most efficient statin in this assay was cerivastatin which was effective at concentration as low as $0.1 \mu \mathrm{M}$. Atorvastatin, cerivastatin, and simvastatin dose dependently decreased cell viability to the same extent in three other human osteosarcoma cell lines (MG63, U2OS and CAL-72) which display different phenotypic characteristics (Table 1). These results show that lipophilic but not hydrophilic statins induce DNA fragmentation and reduce cell viability in several human osteosarcoma cells, independently of osteosarcoma cell characteristics.

A usual characteristic of the apoptotic process is induction of caspase activity. To investigate whether statins reduced cell viability by induction of programmed cell death, we evaluated caspase activity in osteosarcoma cells treated with statins. As shown in Figure 1c, lipophilic statins $(10 \mu \mathrm{M})$ induced a eight- to 12-fold increase in caspase-3 like activity at $24 \mathrm{~h}$ in $\mathrm{SaOS}_{2}$ cells. Again, pravastatin had no significant effect. Similarly, lipophilic statins induced a four- to 35-fold increase in caspase-3 like activity in $\mathrm{OHS}_{4}$ cells (Figure 1c). This effect was not restricted to these two cell lines because statins increased caspase-3 like activity by up to 25 -fold in three other osteosarcoma cell lines which exhibit different characteristics (Table 2). Notably, statins increased caspase3 like activity in CAL-72 cells that are resistant to various chemotherapies. $^{22}$ We also found that lipophilic statins increased caspase- 9 activity at an early time point (15 h), whereas caspase-8 activity or Fas/FasL expression were not significantly changed (data not shown), indicating that statins activated caspase- 9 upstream of caspase-3 in these osteosarcoma cells. To confirm that statins activate caspases in $\mathrm{SaOS}_{2}$ and $\mathrm{OHS}_{4}$ human osteosarcoma cells, the cells were pretreated for $1 \mathrm{~h}$ with $\mathrm{z}$-Val-Ala-Asp-fluoromethylketone (zVAD-fmk), a broad spectrum caspases inhibitor which blocks apoptotic cell death induction but not necrotic cell death. As shown in Figure 1d, zVAD-fmk completely prevented cell death induction by lipophilic statins. These results show that lipophilic statins decrease human osteosarcoma cell viability by induction of caspase-dependent apoptosis.

\section{Statin-induced osteosarcoma cell apoptosis occurs independently of BMP-2 and cell differentiation}

Statins were previously found to activate the BMP-2 promoter and thereby to promote osteoblast differentiation. ${ }^{19,20}$ As we previously showed that BMP-2 promotes human osteosarcoma cell apoptosis through BMPR-IB signaling, ${ }^{18}$ we tested the hypothesis that statins may induce osteosarcoma cell apoptosis by increasing BMP-2 production. To this goal, we compared the effects of statins in $\mathrm{SaOS}_{2}$ cells that express BMP-RIB and $\mathrm{OHS}_{4}$ cells that do not express this receptor. ${ }^{18}$ In basal conditions, both $\mathrm{SaOS}_{2}$ and $\mathrm{OHS}_{4}$ cell lines expressed BMP-2 mRNA, as shown by reverse transcription-polymerase chain reaction (RT-PCR) (Figure 2a) and Western blot analyses (Figure 2b). In both $\mathrm{SaOS}_{2}$ or $\mathrm{OHS}_{4}$ cells, lipophilic statins induced a marked increase in BMP-2 protein released in culture supernatants at $72 \mathrm{~h}$ (Figure 2c). In contrast, statins had no detectable effect on BMP-2 mRNA or protein levels at $24-48 \mathrm{~h}$ of treatment in the two cell lines (data not shown). Thus, the late increase in BMP-2 production occuring at $72 \mathrm{~h}$ (Figure $2 \mathrm{c}$ ) does not correlate with the rapid proapoptotic effect of statins observed at $24 \mathrm{~h}$ of treatment (Figure 1). The finding that BMP-RIB-deficient $\mathrm{OHS}_{4}$ cells that do not respond to the proapoptotic effect of BMP-2, ${ }^{18}$ did respond to the proapoptotic effect of statins (Figure $1 \mathrm{~b}$ ) also discards the involvement of BMP signaling in statin-induced apoptosis. To confirm this hypothesis, we transiently transfected a plasmid encoding noggin, a potent antagonist of BMP $-2,{ }^{23}$ in $\mathrm{SaOS}_{2}$ cells which respond to the proapoptotic effect of BMP-2. ${ }^{18}$ As shown in Figure 2d, noggin over- 

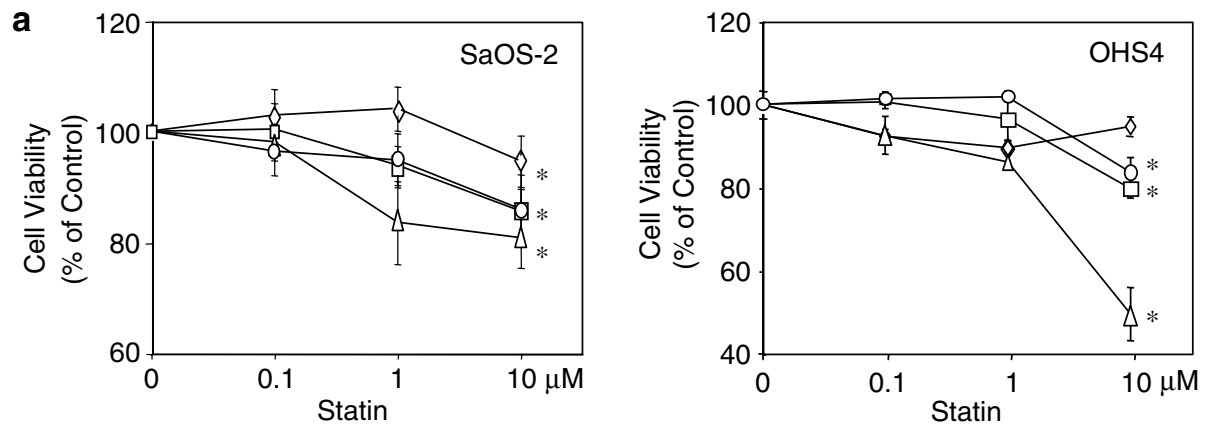

b
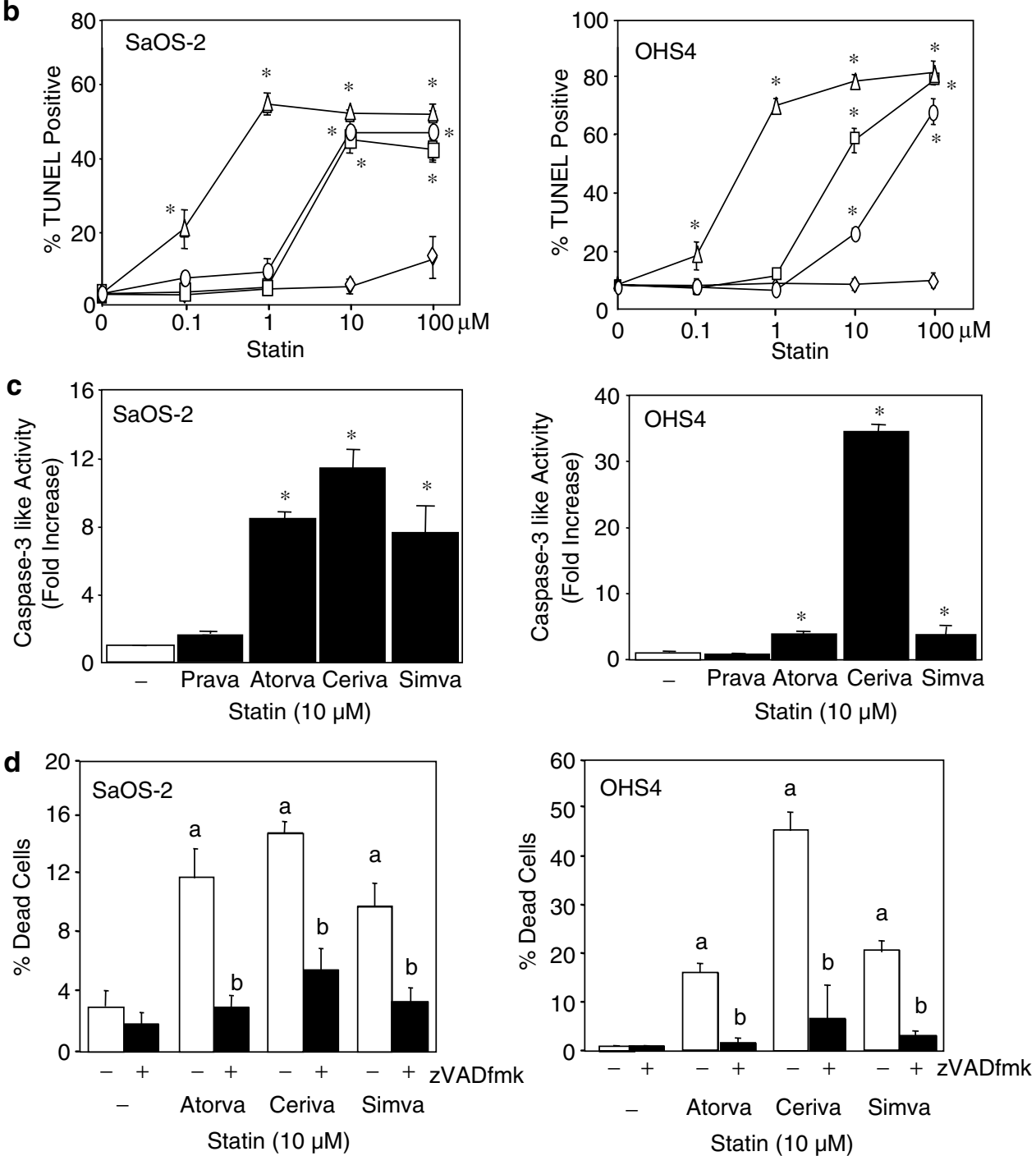

Figure 1 Lipophilic statins induce caspases-dependent apoptosis in human osteosarcoma cells. $\mathrm{SaOS}_{2}$ and $\mathrm{OHS}_{4}$ human osteosarcoma cells cultured in serum supporting conditions were treated for $24 \mathrm{~h}$ with increasing concentrations of atorvastatin $(\square)$, cerivastatin $(\triangle)$, simvastatin $(O)$, pravastatin $(\diamond)$ or the solvent and cell viability was determined using the MTT test (a) and TUNEL staining (b). (c) $\mathrm{SaOS}_{2}$ and $\mathrm{OHS}_{4}$ human osteosarcoma cells were treated for $24 \mathrm{~h}$ with $10 \mu \mathrm{M}$ of the indicated statin or the solvent and caspase-3 like activity was evaluated as described in Materials and Methods. (d) $\mathrm{SaOS}_{2}$ and $\mathrm{OHS}_{4}$ cells were pretreated or not for $1 \mathrm{~h}$ with the broad caspase inhibitor ZVAD-fmk $(25 \mu \mathrm{M})$ before treatment for $24 \mathrm{~h}$ with the indicated statin $(10 \mu \mathrm{M})$ or the solvent. Cell viability was evaluated by cell counting using Trypan blue exclusion. Results are expressed as mean \pm S.E.M. a: ${ }^{*}<<0.05$ versus control cells, b: $P<0.05$ versus without zVAD-fmk

expression did not prevent the increase in caspase-3 like activity induced by statins at $24 \mathrm{~h}$, which does not support a role for BMP-2 in statin-induced apoptosis in osteosarcoma cells.
As BMP-2 promotes osteoblast differentiation in human osteoblastic cells and osteosarcoma cells by inducing Runx2 expression and Runx2-dependent genes, ${ }^{10,18}$ we also determined whether the proapoptotic effect of statins in 
osteosarcoma cells may be linked to the induction of cell differentiation. To this goal, we evaluated the expression level of phenotypic osteoblast differentiation markers in $\mathrm{SaOS}_{2}$ and

Table 1 Lipophilic statins decrease cell viability in human osteosarcoma cells with different phenotypic characteristics

\begin{tabular}{llll}
\hline & MG63 & U2OS & CAL-72 \\
\hline Atorvastatin & $77 \pm 3^{*}$ & $85 \pm 1^{*}$ & $72 \pm 3^{*}$ \\
Cerivastatin & $81 \pm 2^{*}$ & $77 \pm 1^{*}$ & $86 \pm 1^{*}$ \\
Simvastatin & $83 \pm 2^{*}$ & $97 \pm 2$ & $76 \pm 4^{*}$
\end{tabular}

Statins were tested at a concentration of $10 \mu \mathrm{M}$. Data are expressed as percentage of values in untreated cells (mean \pm S.E.M., $n=8$ ) ${ }^{\star} P<0.05$ versus untreated cells
$\mathrm{OHS}_{4}$ cells treated with statins. Treatment with statins for 24 $48 \mathrm{~h}$ had no effect on Runx2, ALP or OC expression in either $\mathrm{SaOS}_{2}$ or $\mathrm{OHS}_{4}$ cells (data not shown). These osteoblast

Table 2 Lipophilic statins increase caspase-3 like activity in human osteosarcoma cells

\begin{tabular}{lccc}
\hline & MG63 & U2OS & CAL-72 \\
\hline Atorvastatin & $13.2 \pm 1.3^{*}$ & $1.6 \pm 0.1^{*}$ & $2.9 \pm 0.5^{\star}$ \\
Cerivastatin & $24.8 \pm 5.9^{*}$ & $7.3 \pm 0.5^{\star}$ & $2.2 \pm 1.4^{*}$ \\
Simvastatin & $13.7 \pm 1.2^{*}$ & $4.4 \pm 1.5^{\star}$ & $2.5 \pm 0.2^{*}$ \\
\hline
\end{tabular}

Statins were tested at a concentration of $10 \mu \mathrm{M}$. Data are expressed as -fold increase versus untreated cells (mean + S.E.M.) ${ }^{*} P<0.05$ versus control a
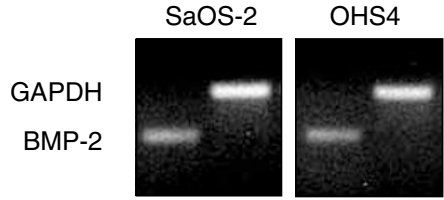

C

BMP-2

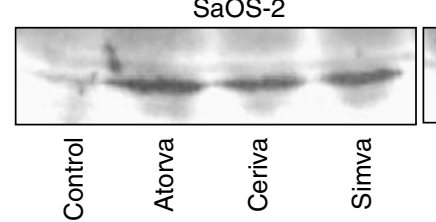

b

BMP-2

B-Actin

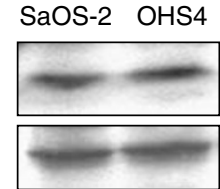

OHS4
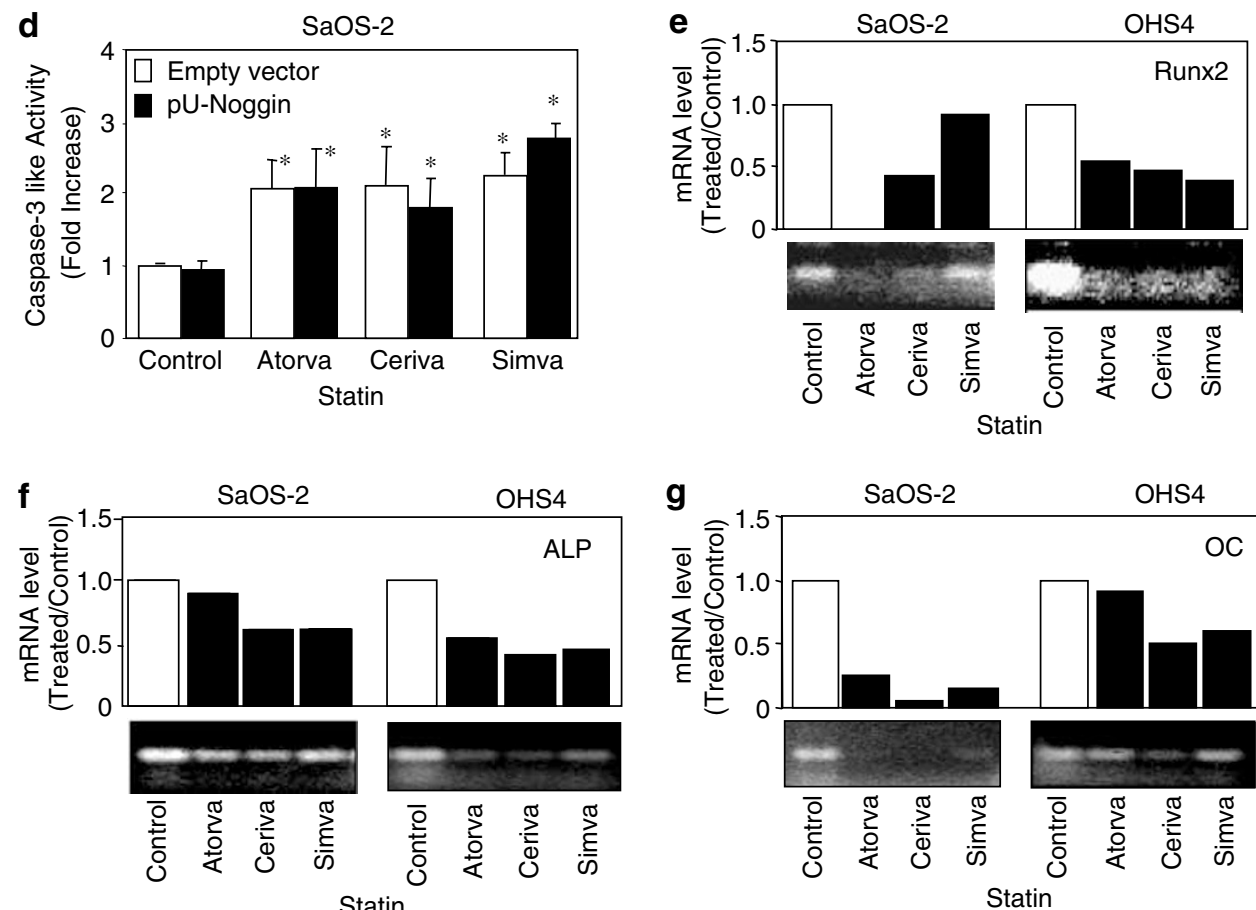

Figure 2 Statin-induced osteosarcoma cell apoptosis occurs independently of BMP-2 and cell differentiation. (a) Basal expression of BMP-2 mRNA was determined by semiquantitative RT-PCR analysis in $\mathrm{SaOS}_{2}$ and $\mathrm{OHS}_{4}$ osteosarcoma cells. Amplification control was the GAPDH housekeeping gene. (b) BMP-2 protein levels were determined by Western blot analysis in cell lysates from $\mathrm{SaOS}_{2}$ and $\mathrm{OHS}_{4}$ cells. (c) Modulation of BMP-2 protein level in SaOS ${ }_{2}$ and $\mathrm{OHS}_{4}$ cell supernatants was determined by Western blot analysis after treatment with the indicated statin $(10 \mu \mathrm{M}, 72 \mathrm{~h})$ or the solvent. (d) $\mathrm{SaOS}_{2}$ cells were transiently transfected with a noggin expression vector or the empty vector before treatment with the indicated statin $(10 \mu \mathrm{M})$ or the solvent for $24 \mathrm{~h}$, and caspase-3-like activity was determined. Results (mean \pm S.E.M.) are expressed as the ratio of noggin overexpressing cells to empty vector-transfected cells. ${ }^{*} P<0.05$ versus control cells. (e-g) Semiquantitative RTPCR analysis of Runx2, ALP and OC mRNA showing the lack of induction of osteoblast markers by the indicated statin (10 $\mu \mathrm{M})$ in $\mathrm{SaOS}_{2}$ and $\mathrm{OHS}_{4}$ cells at $72 \mathrm{~h}$ of treatment. Amplification control was the GAPDH housekeeping gene. Results are expressed as treated over control ratio 
markers were not increased but were rather decreased after $72 \mathrm{~h}$ of treatment with statins, reflecting the induction of apoptosis (Figure $2 \mathrm{e}-\mathrm{g}$ ). Altogether, these results indicate that statins induce apoptosis in osteosarcoma cells independently of BMP-2 expression or signaling and cell differentiation.

\section{Statin-induced osteosarcoma cell apoptosis involves GGPP}

Statins inhibit HMG-CoA reductase, which results in decreased mevalonate levels. ${ }^{5,6}$ To investigate the involvement of defective mevalonate in the proapoptotic effect of statins, $\mathrm{SaOS}_{2}$ and $\mathrm{OHS}_{4}$ cells were supplemented with mevalonate before testing the effects of statins on cell viability. As shown in Figure $3 a$, pretreatment with mevalonate fully prevented the effect of atorvastatin and simvastatin on cell viability, and partially reduced cell death induced by cerivastatin in both cell lines. Consistantly, pretreatment with mevalonate prevented the induction of caspase-3 like activity induced by lipophilic statins in both $\mathrm{SaOS}_{2}$ and $\mathrm{OHS}_{4}$ cells (Figure $3 \mathrm{~b}$ ). This indicates that statin-induced osteosarcoma cell apoptosis involves mevalonate. Since inhibition of HMG-CoA reductase also leads to the depletion of GGPP and FPP which are metabolites derived from mevalonate, ${ }^{6}$ we tested whether GGPP or FPP supplementation may block the effect of statins on apoptosis. As shown in Figure 3c, pretreatment of $\mathrm{SaOS}_{2}$ or $\mathrm{OHS}_{4}$ cells with GGPP completely prevented caspase-3like activity induced by atorvastatin or simvastatin, and markedly reduced the effect of cerivastatin on caspase-3-like activity. In contrast, pretreatment with FPP did not significantly modulate statin-induced caspase-3-like activity (Figure $3 c$ ). These results show that statin-induced apoptosis involves GGPP, an effective metabolite of the mevalonate pathway.
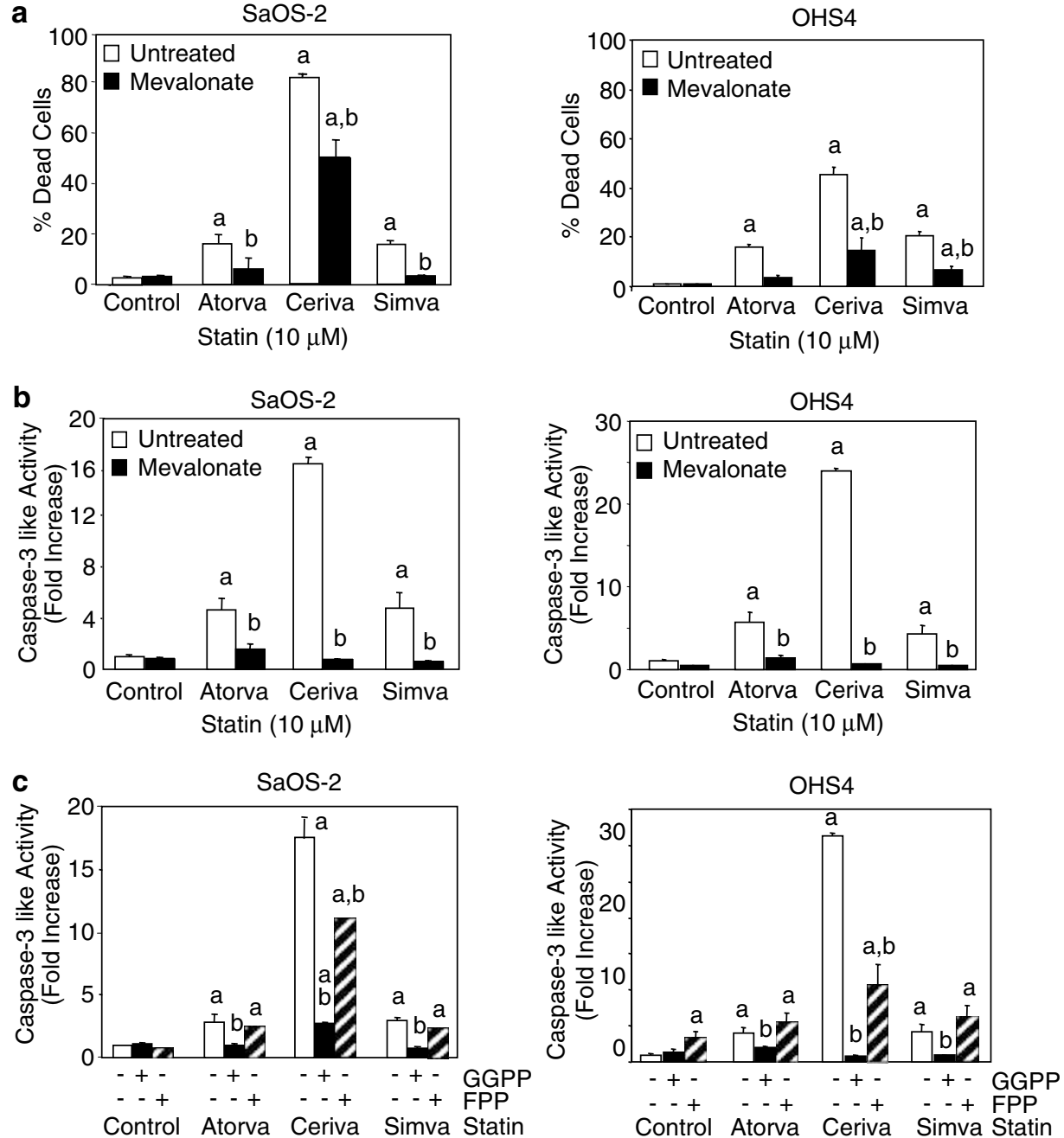

Figure 3 Statin-induced osteosarcoma cell apoptosis involves GGPP. (a and b) $\mathrm{SaOS}_{2}$ and $\mathrm{OHS}_{4}$ osteosarcoma cells were preincubated for $1 \mathrm{~h}$ with or without mevalonate $(1 \mathrm{mM})$ before treatment with the indicated statin $(10 \mu \mathrm{M})$ or the solvent for $24 \mathrm{~h}$. Cell viability (a) was evaluated by cell counting using trypan blue exclusion and the results (mean + S.E.M.) were expressed as percentage of dead cells. Caspase-3-like activity (b) was determined and the results (mean + S.E.M.) expressed as treated over controls. (c) $\mathrm{SaOS}_{2}$ and $\mathrm{OHS}_{4}$ cells cultured in serum-supporting conditions were preincubated for $1 \mathrm{~h}$ with or without GGPP (10 mM) or FPP (10 mM) before treatment with the indicated statin $(10 \mu \mathrm{M})$ or the solvent. Caspase-3-like activity was determined and the results (mean + S.E.M.) were expressed as treated over control ratio. a: $P<0.05$ versus control cells; $b$ : $P<0.05$ versus statin alone. Cells were cultured in serum-supporting conditions in all experiments 


\section{Statin-induced osteosarcoma cell apoptosis involves relocalization and inhibition of RhoA}

Several proteins involved in signaling, such as the Rho family are dependent on prenylation for their correct cellular localization and activity. By inhibition of HMG-CoA reductase, statins block the mevalonate pathway and consequently, Rho prenylation. Prenylation of proteins generally results in translocation from the cytosol to a membrane. We therefore investigated the localization and activity of RhoA protein under lipophilic statins treatment in $\mathrm{SaOS}_{2}$ cells, a representative cell line which responds to statins like other cell lines (Figure 1, Table 1). To this goal, $\mathrm{SaOS}_{2}$ cells were treated with statins and submitted to subcellular fractionation, then RhoA protein expression was evaluated in membrane and cytosolic fractions. In basal conditions, RhoA was found both in the cytosol and anchored to cellular membranes (Figure 4a). Treatment with various doses of statins $(1-10 \mu \mathrm{M})$ resulted in relocalization from membranes to the cytosol (Figure 4a), indicating that inhibition of HMG-CoA reductase by statins blocked RhoA prenylation. To determine whether this effect of statins was dependent on defective metabolites of the mevalonate pathway, we tested whether mevalonate, GGPP or FPP supplementation may block RhoA relocalization. Pretreatment with mevalonate or GGPP prevented RhoA relocalization to the cytosol induced by atorvastatin, whereas pretreatment with FPP had no effect (Figure 4b). Similar effects were observed with simvastatin (data not shown), indicating that statins-
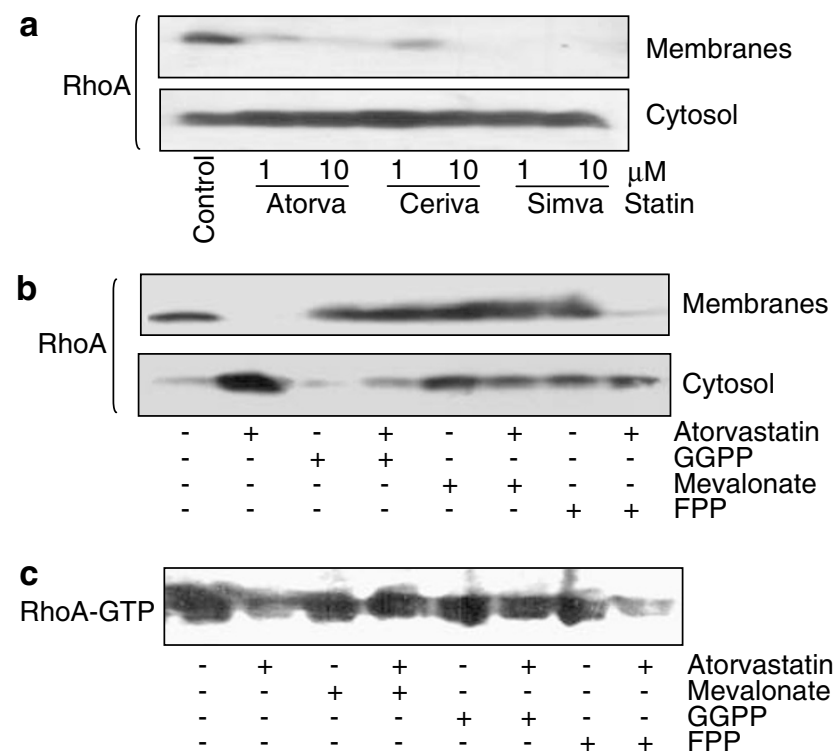

Figure 4 Statin-induced osteosarcoma cell apoptosis involves relocalization and inhibition of RhoA. (a) $\mathrm{SaOS}_{2}$ osteosarcoma cells were incubated for $24 \mathrm{~h}$ with the indicated statin $(1$ or $10 \mu \mathrm{M})$ or the solvent, lysed and submitted to subcellular fractionation. The expression of RhoA in membranous and cytosolic fractions was determined by Western blot analysis. (b) $\mathrm{SaOS}_{2}$ cells were preincubated for $1 \mathrm{~h}$ with mevalonate $(1 \mathrm{mM})$, GGPP $(10 \mathrm{mM})$ or FPP $(10 \mathrm{mM})$ before treatment with or without atorvastatin $(10 \mu \mathrm{M})$ or the solvent for $24 \mathrm{~h}$, then lysed and submitted to subcellular fractionation. The expression of RhoA in the membranous and cytosolic fractions was determined by Western blot analysis. (c) $\mathrm{SaOS}_{2}$ cells were treated as in (b) and the level of RhoA-GTP form was determined using the Rhotekin-binding domain protein as described in Materials and Methods. Cells were cultured in serum-supporting conditions in all experiments induced RhoA relocalization to the cytosol can be reversed by mevalonate or GGPP supplementation. Since correct localization is necessary for RhoA GTPase activity, we evaluated active RhoA levels in response to statins. As shown in Figure 4c, treatment with atorvastatin for $6 \mathrm{~h}$ decreased the level of the RhoA-GTP form, the active form of RhoA, indicating reduced RhoA activity. This inhibitory effect of statin on RhoA activity was prevented by pretreatment with mevalonate or GGPP, but not FPP (Figure 4c). Similar data were obtained using simvastatin (data not shown). These results show that inhibition of HMG-CoA reductase by statins in human osteosarcoma cells leads to RhoA relocalization and inhibition of RhoA activity, as a result of statin-induced decrease in GGPP levels.

We then determined whether the rapid RhoA relocalization and inhibition induced by statins correlates with induction of cell death. To this end, $\mathrm{SaOS}_{2}$ cells were treated for $2-7 \mathrm{~h}$ with atorvastatin, washed and cultured in the absence of atorvastatin for up to $24 \mathrm{~h}$, then cell death was evaluated by caspase3 like activity. Strikingly, caspase-3 like activity was almost maximally increased by only $7 \mathrm{~h}$ of atorvastatin treatment (Figure 5a). Consistently, cell treatment with atorvastatin for only $6 \mathrm{~h}$ was sufficient to relocalize the major part of RhoA from the membranes to the cytosolic fraction (Figure $5 b$ ). Similar effects were obtained using simvastatin (data not shown). These results indicate that lipophilic statins rapidly induce cell death after only $6-7 \mathrm{~h}$ of treatment, a time point that correlates with the complete relocalization of RhoA from membranes to the cytosol in human osteosarcoma cells.

To further establish the role of RhoA activity in cell death induced by lipophilic statins, $\mathrm{SaOS}_{2}$ cells were transiently transfected with either a wild-type form (WT) of RhoA or a constitutively active form (CA) of RhoA (RhoA-G14V) coupled to GFP. Transfection efficiency, evaluated by the number of GFP-positive cells, averaged 8-14\%, and Western blot analysis confirmed the overexpression of RhoA-GFP in $\mathrm{SaOS}_{2}$-transfected cells (Figure $5 \mathrm{c}$ ). Overexpression of the CA of RhoA markedly inhibited caspase-3-like activity induced by atorvastatin. In contrast, no effect was observed using the WT of RhoA (Figure $5 \mathrm{~d}$ ). These results show that apoptosis induced by statins can be rescued by constitutively active Rho $A$, indicating that the activity of RhoA is required to protect against statin-induced human osteosarcoma cell death.

\section{RhoA inactivation induces osteosarcoma cell apoptosis by reducing phospho-p42/p44-MAPKs and $\mathrm{Bcl}-2$ signaling}

We finally investigated the intracellular signaling pathways that are involved in statin-induced apoptosis in osteosarcoma cells. MAPKs and phosphoinositide $3^{\prime}$ kinase (PI3K) are key signaling pathways controlling cell survival. However, the implication of these signaling cascades in statin's effects in cancer cells remains conflicting. ${ }^{6}$ We found that inhibition of PI3K activity with the specific PI3K inhibitor LY294004 (1-25 $\mu \mathrm{M}, 24-48 \mathrm{~h}$ ) had no effect on caspase-3-like activity in $\mathrm{SaOS}_{2}$ and $\mathrm{OHS}_{4}$ osteosarcoma cells (data not shown), which does not support a major role for PI3K in the control of cell death in these cells. To determine whether the MAPKs 
a
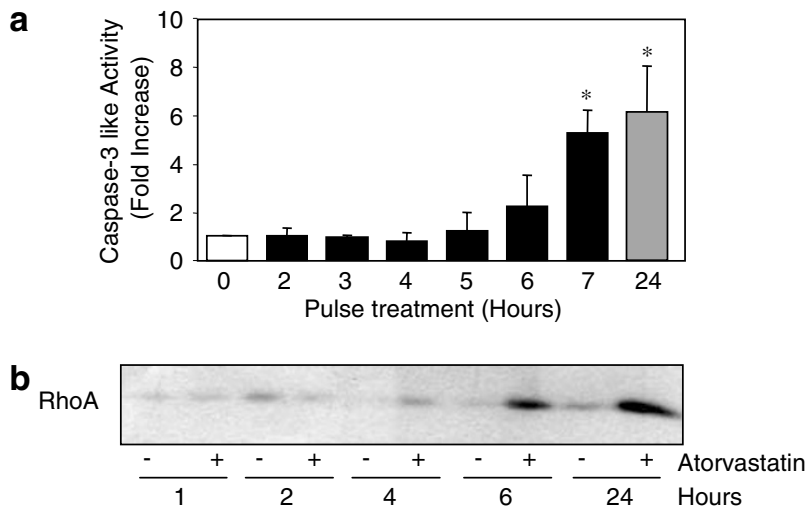

C

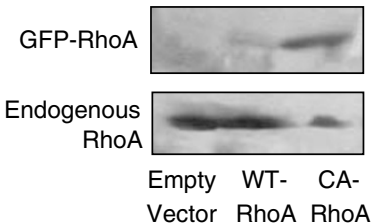

d

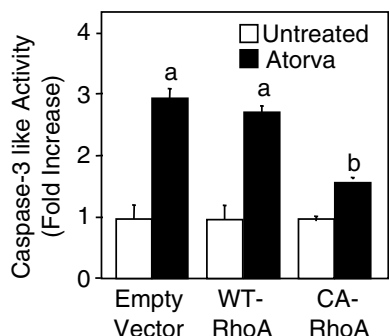

Figure 5 Constitutively active RhoA prevents statin-induced human osteosarcoma cell death. (a) $\mathrm{SaOS}_{2}$ osteosarcoma cells were incubated for $2-24 \mathrm{~h}$ in the presence of atorvastatin $(10 \mu \mathrm{M})$, washed and incubated without atorvastatin for the remaining period of time for up to $24 \mathrm{~h}$, and caspase-3 like activity was determined. ${ }^{*} P<0.05$ versus control. (b) SaOS 2 cells were incubated for $1-24 \mathrm{~h}$ with atorvastatin $(10 \mu \mathrm{M})$, lysed and submitted to subcellular fractionation. Expression of RhoA in the membranous and cytosolic fractions was determined by Western blot analysis. (c and d) $\mathrm{SaOS}_{2}$ cells were transiently transfected with the expression plasmid pEGFP alone or encoding the sequence of wild-type RhoA (WT-RhoA) or the constitutively active (CA) form of RhoA (G14V mutant). Western blot analysis (c) shows detectable endogenous RhoA in all conditions low expression of the GFP-coupled form of RhoA in WT-RhoA-transfected cells and marked expression in CA-RhoA-transfected cells. (d) $\mathrm{SaOS}_{2}$-transfected cells were incubated for $24 \mathrm{~h}$ with atorvastatin $(10 \mu \mathrm{M})$ or the solvent. Caspase-3like activity was determined and the results (mean \pm S.E.M.) expressed as treated over control ratio. a: $P<0.05$ versus untreated cells, b: $P<0.05$ versus empty vector-transfected cells. Cells were cultured in serum-supporting conditions in all experiments

pathway is a downtream effector pathway of the RhoA protein, we tested the effect of statins on MAPKs phosphorylation which reflects MAPKs activity. As shown in Figure 6a, treatment with atorvastatin decreased p42/p44-MAPKs phosphorylation by as much as $50 \%$ in $\mathrm{SaOS}_{2}$ cells. Similar results were obtained in $\mathrm{OHS}_{4}$ cells, and in the two cell lines using simvastatin (data not shown), indicating that statins induce MAPK inactivation in osteosarcoma cells. We then tested whether mevalonate, GGPP or FPP supplementation may block the inhibitory effect of statins on MAPKs activation. Significantly, the decrease in phospho-p42/p44-MAPKs levels induced by atorvastatin was prevented by pretreatment with mevalonate or GGPP, but not FPP (Figure 6b). These results indicate that statins decrease phosphorylation of $\mathrm{p} 42 /$ p44-MAPKs in human osteosarcoma cells as a result of decreased protein geranylgeranylation.

To identify the molecular effectors involved in statininduced apoptosis, we analysed the changes in the expression of pro- and antiapoptotic molecules in response to statins. As shown in Figure 6c, atorvastatin induced PARP cleavage, confirming the induction of apoptosis. Mcl-1 and $\mathrm{Bcl}-2$ are two antiapoptotic proteins that are targets for MAPKs in some cells. ${ }^{24,25}$ In osteosarcoma cells, we found that atorvastatin decreased $\mathrm{Mcl}-1$ and $\mathrm{Bcl}-2$ levels (Figure $6 \mathrm{c}$ ). Interestingly, atorvastatin had no effect on the proapoptotic protein Bax (Figure 6c) or on Bcl-xl, Bid or Bim, which are other modulators of apoptosis (data not shown). Semiquantitative evaluation of mRNA expression confirmed that lipophilic statins reduced by $70 \% \mathrm{Bcl}-2$ gene expression in $\mathrm{SaOS}_{2}$ cells, whereas Bax or the inhibitor of apoptosis (IAP) survivin mRNA levels remained unaffected (Figure 6d). The overall inhibitory effect of statins on Bcl-2 expression resulted in a three- to four-fold increase in the Bax to Bcl-2 ratio, showing that statins turned the ratio of pro- to antiapoptotic effectors in favour of apoptosis induction in osteosarcoma cells.

To further investigate the role of RhoA in the decreased MAPKs activity and Bcl-2 levels induced by statins, $\mathrm{SaOS}_{2}$ cells were transfected with WT-RhoA or CA-RhoA-G14V. In contrast to WT-RhoA, overexpression of CA-RhoA prevented the statin-induced decrease in p42/p44-MAPKs phosphorylation rate (Figure 6e), implicating RhoA in the statin-induced decreased MAPKs activity. Consistently, overexpression of constitutively active RhoA prevented the inhibitory effect of atorvastatin on $\mathrm{Bcl}-2$ levels whereas wild-type RhoA had no effect. Finally, because RhoA was reported to stimulate cell cycle progression through inactivation of the Cdk inhibitor p27KIP $1,{ }^{26}$ we determined whether statin-induced apoptosis may be associated with altered p27 expression in osteosarcoma cells. As shown in Figure $6 \mathrm{~g}$, atorvastatin increased p27 expression. However, neither wild-type RhoA, nor constitutively active RhoA corrected the increased p27 expression in statin-treated osteosarcoma cells. These results indicate that RhoA protects against statin-induced human osteosarcoma cell death by interacting with the p42/p44-MAPKs and $\mathrm{Bcl}-2$ survival pathway, independently of p27.

\section{Discussion}

The present data show that lipophilic statins, by inhibiting HMG-CoA reductase, induce apoptosis in human osteosarcoma cells by a RhoA-p42/p44 MAPKs-Bcl-2-mediated mechanism that is independent of BMP-2 signaling and cell differentiation. Importantly, we found that statins-induced apoptosis in various osteosarcoma cell lines cultured in growth supporting conditions, independently of their phenotypic characteristics. Consistent with other findings in acute myeloid leukaemic cell lines ${ }^{27}$ cerivastatin was more potent than atorvastatin and simvastatin to induce osteosarcoma cell death. Also, pravastatin was not efficient to induce apoptosis, in accordance with its hydrophilic nature. Notably, we found that osteosarcoma cell death induced by lipophilic statins is a caspase-dependent apoptotic process, which is consistent with recent studies in non osseous cells. ${ }^{28,29}$ Since we found that statins activated caspase- 9 and -3-like activity, but not caspase-8 activity, in a time-dependent manner, we conclude that lipophilic statins induce apoptosis in human osteosarcoma cells mostly through activation of the mitochondrial apoptotic pathway. 
a
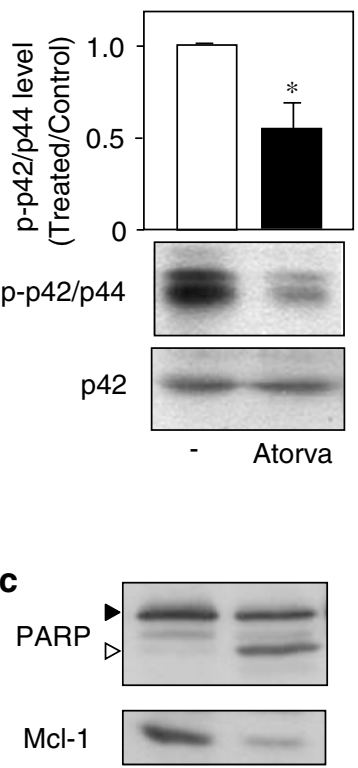

$\mathrm{Bcl}-2$

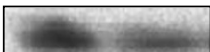

Bax

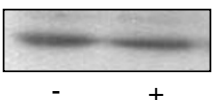

Atorvastatin b

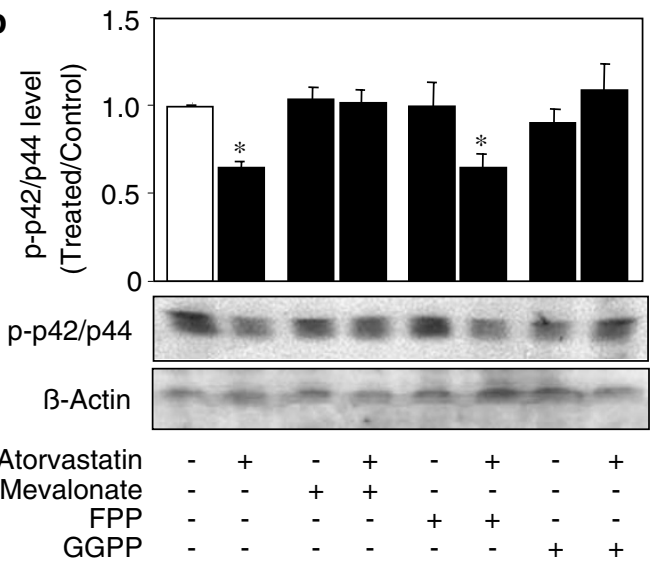

d

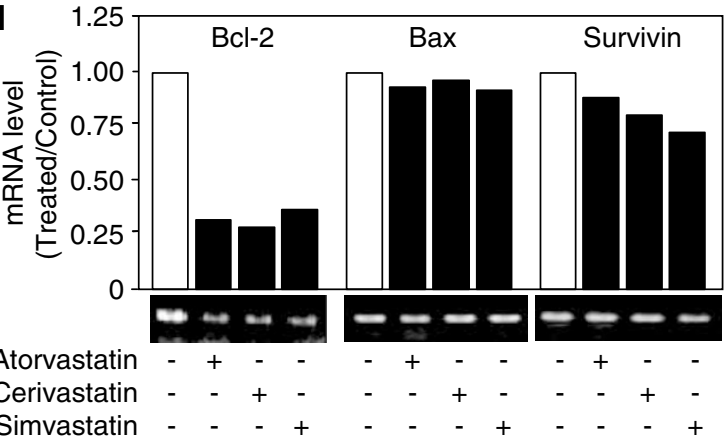

e

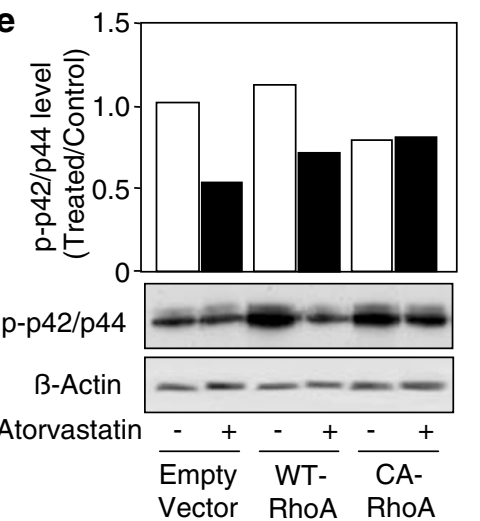

f

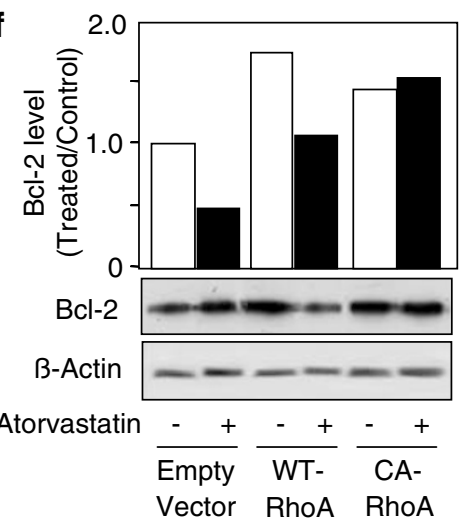

g

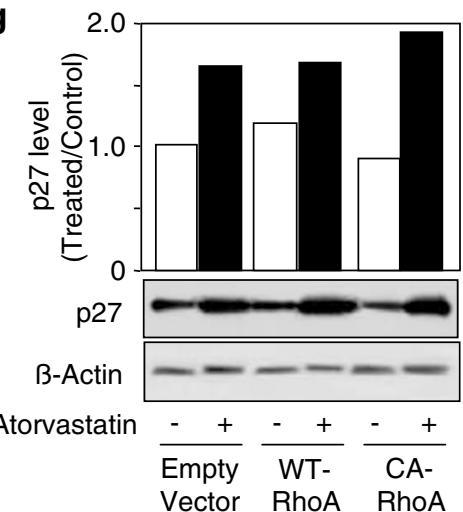

Figure 6 RhoA inactivation induces osteosarcoma cell apoptosis by reducing phospho-p42/p44-MAPKs and Bcl-2 signaling. (a) SaOS ${ }_{2}$ cells were incubated with

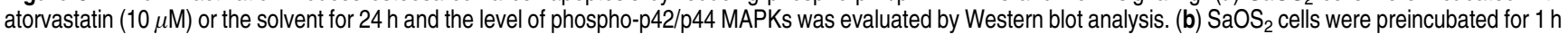
with or without mevalonate $(1 \mathrm{mM})$, FPP $(10 \mathrm{mM})$ or GGPP $(10 \mathrm{mM})$ before treatment with atorvastatin $(10 \mu \mathrm{M})$ or the solvent for $24 \mathrm{~h}$, and the level of phospho-p42/p44 MAPKs was evaluated by Western blot analysis. Results (mean \pm S.E.M.) are expressed as treated over control ratio. ${ }^{*} P<0.05$ versus control. (c) SaOS 2 cells were incubated for $24 \mathrm{~h}$ with atorvastatin $(10 \mu \mathrm{M})$ or the solvent and the expression of PARP, Mcl-1, Bcl-2 and Bax was evaluated by Western blot analysis. The black arrowhead indicates full-length PARP and the white arrowhead shows the cleaved fragment of PARP. (d) $\mathrm{SaOS}_{2}$ cells were incubated for $24 \mathrm{~h}$ with atorvastatin (10 $\mu \mathrm{M}$ ) or the solvent, the expression of $\mathrm{Bcl}-2, \mathrm{Bax}$ and IAP/survivin was evaluated by semiquantitative RT-PCR analysis and the results expressed as treated over control ratio after correction for the housekeeping gene GAPDH. (e-g) $\mathrm{SaOS}_{2}$ cells were transiently transfected with the expression plasmid pEGFP alone or encoding the sequence of wild-type (WT) RhoA or constitutively active (CA) form of RhoA (G14V mutant), then treated with atorvastatin (10 $\mu \mathrm{M}$ ) or the solvent for $24 \mathrm{~h}$, and the levels of phosphop42/p44 MAPKs (e), Bcl-2 (f) and p27 (g) were determined by Western blot analysis. Results are expressed as treated over control ratio after correction for $\beta$-actin expression. Cells were cultured in serum-supporting conditions in all experiments

Because statins were shown to induce BMP-2 expression and cell differentiation in osteoblastic cells, ${ }^{19-21}$ we explored the possibility that statins may exert apoptotic activity through induction of BMP signaling in osteosarcoma cells. Our finding that statins induced rapid cell apoptosis independently of BMP-2 or BMPR-IB expression, and that apoptosis was not abolished by the natural BMP antagonist noggin does not support a role for BMP signaling in osteosarcoma cell death induced by statins. Since BMP-2 promotes osteoblast differentiation, a related question was to determine whether statins may induce osteosarcoma cell apoptosis secondary to cell differentiation. Indeed, recent evidence indicate that 
osteosarcoma is associated with reduced Runx2 and Osterix expression whereas overexpressing Runx2 or Osterix induces cell differentiation in osteosarcoma cells, ${ }^{16,30}$ an effect that is reproduced by BMP-2. ${ }^{18}$ In the present study, Runx2 and phenotypic osteoblast differentiation markers declined under statin treatment, which indicates that statin-induced apoptosis did not occur secondary to cell differentiation. This strengthens the growing concept that osteosarcoma cell apoptosis can be induced independently of cell differentiation. ${ }^{18}$ In addition to promote osteoblast commitment, Runx2 may induce osteoblast growth arrest ${ }^{13,14}$ in part through the Cdk inhibitor $\mathrm{p} 27^{16}$ which regulates the transition between proliferation and differentiation in osteoblasts. ${ }^{13}$ In that way, loss of Runx2 and p27 expression is associated with disrupted differentiation in osteosarcoma cells. ${ }^{16}$ As RhoA is known to control p27 protein levels, ${ }^{26}$ RhoA inactivation by statins may alter p27 expression and thereby control growth arrest and apoptosis. Our finding that the upregulation of p27 by statins was not reversed by CA-RhoA despite reversal of apoptosis indicates that p27 is not involved in statin-induced apoptosis in osteosarcoma cells. Thus, osteosarcoma cell death induction by statins is independent of BMP-2 signaling and p27 expression.

The biosynthesis cascade of cholesterol from acetylcoenzyme $A$ leads to the generation of isoprenoid residues such as GGPP and FPP which are transferred to proteins such as small GTPases by geranylgeranyltransferase and farnesyltransferase, respectively. The additional lipidic chain ensures proper localization to membranes of isoprenylated proteins. Statins, by blocking the HMG-CoA reductase, lead to deprivation of mevalonate and downstream metabolites such as mevalonate, GGPP or FPP. ${ }^{5,6}$ Our finding that mevalonate and GGPP preferentially diminished the proapoptotic effect of statins relative to FPP points to a predominant role of protein geranylgeranylation in statin-induced apoptosis in osteosarcoma cells. Consistent with our finding in osteosarcoma cells is the related observation in osteoclasts and human myeloma cells that inhibition of the mevalonate pathway by nitrogencontaining bisphosphonates induces apoptosis through inhibition of geranylgeranylated small GTPases. ${ }^{31}$ Among geranylgeranylated GTPases, RhoA has been reported to exert positive and negative role in apoptosis, depending on the cell type. ${ }^{5}$ We show here that statins induced relocalization and inactivation of RhoA with a time course consistent with the induction of apoptosis. Since suplementation with GGPP restored the amount of membrane bound-RhoA and fully prevented apoptosis, the defective isoprenylation of RhoA induced by statins appears to be necessary and sufficient to induce cell death in osteosarcoma cells. Although this establishes a key role for RhoA in controlling osteosarcoma cell apoptosis, we cannot exclude the possibility that other geranylgeranylated proteins may also be involved. Recent data from our and other groups suggest a positive effect of RhoA in osteoblast differentiation and osteogenesis. Indeed, increased RhoA expression is associated with premature osteoblast differentiation ${ }^{32}$ and constitutive activation of RhoA promotes osteogenesis in vitro. ${ }^{33}$ The present finding that RhoA inactivation induces osteoarcoma cell death indicates that RhoA also plays a role in osteoblastic cell survival.
An important question was to identify the transduction cascades that are involved in apoptosis induced by RhoA inactivation in osteosarcoma cells. One possible mechanism by which RhoA may control apoptosis is by inhibiting a survival pathway. We investigated the role of PI3K/Akt and p42/p44 MAPKs that are two major signaling pathways that contribute to osteoblastic cell survival, in statin-induced osteosarcoma cell apoptosis. Our data do not support a major role for PI3K in the control of cell death induced by statins in osteosarcoma cells. In contrast, our results indicate that statin-induced apoptosis implicates inhibition of p42/p44-MAPKs phosphorylation. In other cancer cells, the implication of MAPKs in apoptosis appears to be conflicting because statin-induced apoptosis is associated with decreased MAPKs activation in some cells whereas MAPKs is unaffected by statins in other cells. ${ }^{6}$ Moreover, although several studies have implicated Rho proteins in the regulation of MAPK, these proteins have been implicated in both pro- and antiapoptotic signaling. 5,34 In osteosarcoma cells, our finding that CA-RhoA restored MAPKs phosphorylation and prevented statin-induced apoptosis supports a mechanism by which inhibition of RhoA GTPase activity by lipophilic statins induce apoptosis by inhibition of the p42/p44-MAPKs survival pathway.

As the exact role of proteins involved in the induction of apoptosis by statins is unclear due to difference in tumour cell types, ${ }^{5,6,34}$ an important issue was to determine the proteins downstream of RhoA and p42/p44-MAPKs inactivation in osteosarcoma cells. Nitric oxide (NO) production was recently reported to mediate apoptosis induced by statins in nonosseous cells. ${ }^{35}$ Although NO is known to activate osteoblast apoptosis, ${ }^{36}$ we were unable to detect significant modulation of $\mathrm{NO}$ in either $\mathrm{SaOS}_{2}$ or $\mathrm{OHS}_{4}$ osteosarcoma cells under statin treatment (10-100 $\mu \mathrm{M}, 2-48 \mathrm{~h}$; data not shown). We also found that statins had no effect on survivin, an inhibitor of apoptosis which is often overexpressed in tumour cells, ${ }^{37}$ most likely because this protein is rather sensitive to the activity of small GTPases of the Rac/Ras family. In contrast, we found that statins specifically inhibited the expression of the Bcl-2 and Mcl-1, two major antiapoptotic effectors. Our finding that restoration of RhoA activity abolished the inhibition of $\mathrm{Bcl}-2$ and prevented cell death induced by statins indicates that $\mathrm{Bcl}-2$ plays an essential role in protecting osteosarcoma cells from apoptosis induced by RhoA inactivation. Although a link between MAPKs, Bcl-2 and $\mathrm{Mcl}-1$ has been reported in some other cell types, ${ }^{24,25}$ and RhoA inhibition has been linked to $\mathrm{Bcl}-2$ downregulation in the induction of apoptosis by statins in some cancer cells, ${ }^{28,34,38}$ evidence implicating these molecules in the mechanisms of action of statins in human osteosarcoma cells was lacking. The present results point to a direct implication of $\mathrm{p} 42 / \mathrm{p} 44-\mathrm{MAPKs}$ signaling downstream of RhoA as a mediator of the effects of statins on Bcl-2 and apoptosis in osteosarcoma cells.

Our finding that statins induce osteosarcoma cell apoptosis in vitro raises the interest of determining the efficacy of statins on osteosarcoma development and tumour progression in vivo. The concentrations required for statin-induced osteosarcoma cell apoptosis are unlikely to be therapeutically achieved after administration in vivo. However, combinations of statins and chemotherapeutic agents may augment the response to statins and allow the use of lower doses in vivo. 
Consistently, the administration of pravastatin at low dose $(0.5 \mathrm{mg} / \mathrm{kg} /$ day $)$ in conjunction with 5 -fluorouracil was found to double the median survival time in patients with hepatocellular carcinoma. $^{39}$ In preliminary experiments, we found that the addition of conventional cytotoxic drugs (doxorubicin, $100 \mathrm{ng} / \mathrm{ml}$; cisplatin, $20 \mu \mathrm{M}$ ) to lipophilic statins enhanced by three- to 15-fold osteosarcoma cell death induced by statins (unpublished data), suggesting that statins may be of therapeutic interest when combined with standard therapeutic approaches to enhance osteosarcoma cell apoptosis. Further experimental studies, now in progress, are needed to determine the potential interest of low doses of statins in association with conventional cytotoxic drugs as apoptosistriggering agents on osteosarcoma cell development and tumour progression in vivo.

\section{Materials and Methods}

\section{Cell cultures}

We used human cancer cells derived from different types of osteosarcomas with distinct genetic profiles. Human $\mathrm{SaOS}_{2}$ osteosarcoma cells (ATCC; Rockville, MD, USA) exhibit an undifferentiated osteoblastic phenotype and are deficient for p53. Human $\mathrm{OHS}_{4}$ osteosarcoma cells exhibit an osteoblast phenotype and express p53 but are BMPR-IB deficient. ${ }^{18}$ We also tested statin effects in three other human osteosarcoma cells with different characteristics such as p53 mutant and ARF deficient cells (MG63), ARF mutant cells (U2OS), or chemotherapy-resistant cells (CAL-72). CAL-72 cells display chromosomal abnormalities and a distinct cytokine expression profile compared to MG63 and $\mathrm{SaOS}_{2}$ cells. ${ }^{22}$ All cells were cultured in Dulbecco's-modified Eagle medium (Invitrogen Corporation, Paisley, Scotland) in the presence of $10 \%$ heat inactivated fetal calf serum (FCS), 1\% L-glutamine and penicillin/streptomycin (10000 U/ml and $10000 \mu \mathrm{g} / \mathrm{ml}$, respectively) with medium change every 2-3 days. Importantly, all the experiments described below were performed in cells cultured in serum supporting conditions, i.e., in the presence of $10 \%$ FCS.

\section{Cell viability}

Cell viability was evaluated by the MTT test as previously described ${ }^{40}$ or by cell counting under Trypan blue exclusion. Results are expressed as mean \pm S.E.M. of three independent experiments with tetrareplicates for each condition.

\section{TUNEL analysis}

DNA fragmentation was evaluated using the TUNEL assay (kit Roche, Mannheim, Germany). Positive controls consisted of cells treated with DNAse I for $10 \mathrm{~min}$. Negative controls were obtained by omitting the transferase from the reaction. At least 1500 cells were counted for each experiment and the results are expressed as percentage of TUNELpositive cells.

\section{Caspases activity}

Cells were treated with increasing doses of statins or the solvent for $24 \mathrm{~h}$, and caspases activity was determined. Briefly, cellular extracts $(50 \mu \mathrm{g})$ were incubated with $0.2 \mathrm{mM}$ of acetyl-Asp-Glu-Val-Asp-paraNitroAniline (Ac-DEVD-pNA) (caspases-3, -6, -7; Alexis Biochemicals, CA, USA),
Ac-LEHD-pNA (caspase-9; Alexis Biochemicals) or Ac-IETD-pNA (caspase8; Alexis Biochemicals) as substrates for various times at $37^{\circ} \mathrm{C}$ in the presence or the absence of the specific caspase inhibitors Ac-DEVD$\mathrm{CHO}, \mathrm{Ac}-\mathrm{LEHD}-\mathrm{CHO}$ and Ac-IETD-CHO $(10 \mu \mathrm{M})$. The specific activity (nmol pNA/min/mg protein) was expressed as treated over control ratios.

\section{Subcellular fractionation}

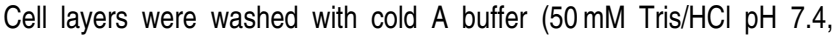
$150 \mathrm{mM} \mathrm{NaCl}, 2 \mathrm{mM} \mathrm{Na}_{3} \mathrm{VO}_{4}$ ), scrapped and centrifuged at 1200 r.p.m. for $5 \mathrm{~min}$ at $4^{\circ} \mathrm{C}$. Cell pellets were sonicated $(10 \mathrm{~s}$, three times) on ice in $\mathrm{B}$ buffer $\left(50 \mathrm{mM}\right.$ Tris $\mathrm{pH} 7.4,250 \mathrm{mM}$ sucrose, $\left.2 \mathrm{mM} \mathrm{Na}_{3} \mathrm{VO}_{4}\right)$, then ultracentrifuged at $100000 \times g$ for $1 \mathrm{~h}$ at $4^{\circ} \mathrm{C}$. Cytosolic fractions (supernatants) were concentrated 20 -fold by ultrafiltration (Centricon $10 \mathrm{~K}$, Millipore Corporation) and supplemented with $1 \mathrm{mM} \mathrm{PMSF}, 10 \mu \mathrm{g} / \mathrm{ml}$ aprotinin and $10 \mu \mathrm{g} / \mathrm{ml}$ leupeptin. Pellets, corresponding to the membrane fraction, were resuspended in Western blot lysis buffer.

\section{RhoA activity assay}

Levels of active RhoA were measured using the Rhotekin Rho Binding Domain protein (Upstate, NY, USA). Briefly, cells were lysed in $(25 \mathrm{mM}$ Hepes, $250 \mathrm{mM} \mathrm{NaCl}, 1 \%$ Ipegal, $10 \mathrm{mM} \mathrm{MgCl}$, $1 \mathrm{mM}$ EDTA, $10 \%$ glycerol, $10 \mu \mathrm{g} / \mathrm{ml}$ aprotinin and $10 \mu \mathrm{g} / \mathrm{ml}$ leupeptin) for $30 \mathrm{~min}$ on ice and insoluble materials were removed by centrifugation. Lysates were incubated for $45 \mathrm{~min}$ at $4^{\circ} \mathrm{C}$ with $30 \mu \mathrm{l}$ of Rhotekin (Rho)-binding domain-agarose gel under agitation. Beads were washed three times with lysis buffer, resuspended in Laemmli buffer and analysed by Western blotting with anti-RhoA monoclonal antibody (Santa Cruz Biotechnology, CA, USA).

\section{Cell transfection}

Transient transfections were performed with Exgen500 (Euromedex, France). At $24 \mathrm{~h}$ after transfection, statins $(10 \mu \mathrm{M})$ were added in $10 \%$ FCS containing medium for further $24 \mathrm{~h}$. The plasmids used were either pU-Noggin, pEGFP-HsRhoA (wild-type RhoA) and pEGFP-HsRhoAG14V (constitutively active RhoA mutant).

\section{Western blot analysis}

Cells were lysed in $\left(50 \mathrm{mM}\right.$ Tris/ $\mathrm{HCl} \mathrm{pH} \mathrm{7.4,150} \mathrm{mM} \mathrm{NaCl}, 10 \mathrm{mM} \mathrm{MgCl}_{2}$, $10 \%$ glycerol, $10 \mathrm{mM} \mathrm{Na}_{3} \mathrm{VO}_{4}, 1 \% \mathrm{NP}-40,1 \mathrm{mM} \mathrm{PMSF}, 10 \mu \mathrm{g} / \mathrm{ml}$ aprotinin, $10 \mu \mathrm{g} / \mathrm{ml}$ leupeptin) for $30 \mathrm{~min}$ on ice, then scapped and centrifuged for $10 \mathrm{~min}$ at $12000 \times g$ at $4^{\circ} \mathrm{C}$ to remove insoluble materials. Protein concentrations in the supernatants were measured using the DC Protein assay (Bio-Rad Laboratories). Proteins $(100 \mu \mathrm{g})$ were resolved on $12 \%$ SDS-PAGE and electrotransferred onto PVDF nitrocellulose membranes (Millipore Corporation, Bedford, USA). Filters were incubated at RT for $2 \mathrm{~h}$ in Tris-Buffered Saline $(50 \mathrm{mM}$ Tris/ $\mathrm{HCl} \mathrm{pH} \mathrm{7.4,} 150 \mathrm{mM}$ $\mathrm{NaCl}$ ) containing $0.1 \%$ Tween- 20 and $0.5 \%$ bovine serum albumin (tris hydroxymethylaminomethane-buffered saline Tween-20 (TBST)/bovin serum albumin (BSA)), then overnight at $4^{\circ} \mathrm{C}$ on a shaker with specific primary antibodies (1/1000 in TBST/BSA) against BMP-2, RhoA, Bax, Bcl-2, PARP, phospho-p42/p44-MAPKs or p42/p44-MAPKs (all from Santa Cruz Biotechnology), p27 (Signal Transduction) or beta-actin (Sigma). Membranes were washed twice with TBST and incubated at RT for $2 \mathrm{~h}$ with appropriate horseradish peroxidase-conjugated secondary antibody (1/20000 in TBST/BSA). After final washes, the signals were visualized with the enhanced chemiluminescence Western blotting detection reagent 
(ECL, Amersham, France) and autoradiographic film (X-OMAT-AR, Eastman Kodak Company, Rochester, NY, USA). Densitometric analysis using ImageQuant software was performed following digital scanning (Agfa).

\section{RNA extraction and RT-PCR analysis}

Total RNA was isolated by phenol/chloroform extraction using TriPure solution, according to the manufacturer's recommendation (Eurobio, France). Concentrations were measured at $260 \mathrm{~nm}$, and RNA quality was checked on formaldehyde-agarose gel stained with ethidium bromide. The relative level of the different mRNA were evaluated by semiquantitative RT-PCR using the same cycle number ( 30 cycles) for all genes, except for glyceraldehyde 3-phosphate deshydrogenase (GAPDH) (25 cycles), in which the amplification was linear. Of total RNA, $3 \mu \mathrm{g}$ from each samples were reverse transcribed and the cDNA samples were then divided and amplified using specific primers ( 20 pmoles/tube). The signal for each gene was corrected for GAPDH. Primers were as follows: sense $5^{\prime}$ CGAGAACAGATGCAAGATGC- $3^{\prime}$, antisense $5^{\prime}$-AGCCACAATCCAGT CATTCC-3' for BMP-2; sense 5'-TGTGTGTGGAGAGCGTCAAC-3', antisense $5^{\prime}$-TGCTTGGCAATTAGTGGTCG-3' for Bcl-2; sense $5^{\prime}$ AGGAGGCTTGAGGAGTCTCA-3', antisense 5'-ACCAGCTCTGAGCA GATCAT-3' for Bax; sense 5'-ACCACCGCATCTCTACATTC-3', antisense $5^{\prime}$-AGAGGCCTCAATCCATGGCA-3' for IAP/survivin and sense $5^{\prime}$ GGGCTGCTTTTAACTCTGGT-3', antisense 5'-TGGCAGGTTTTTCTA GACGG-3' for GAPDH. Primers for ALP, osteocalcin and Runx2 were as described previously. ${ }^{18}$

\section{Data analysis}

The data are representative of 2-3 independent experiments with tetrareplicates for each condition and are expressed as mean \pm S.E.M. Differences between the mean values were evaluated using the Student's $t$-test with a minimal significance of $P<0.05$.

\section{Acknowledgements}

This work was supported in part by Inserm, the Association pour la Recherche Contre le Cancer (ARC Contract \#4315) and the Association Rhumatisme et Travail, Paris, France. We thank Drs. B Fournier and $P$ Price (University of California, San Diego, La Jolla, CA, USA) for providing $\mathrm{OHS}_{4}$ cells, Dr. J Feyen (Bristol Squibb Meyer, USA) for providing statins, Dr. G Rawadi (Proskelia, Romainville, France) for the noggin vector, Drs. $P$ Fort and $P$ Jurdic (ENS, Lyon) for the RhoA constructs, Olivia Bawa for her contribution to this work and Nathalie Rochet (Inserm U364, Faculté de Médecine, Nice, France) for the gift of MG63, U2OS and CAL-72 osteosarcoma cells.

\section{References}

1. Himelstein BP (1998) Osteosarcoma and other bone cancers. Curr. Opin Oncol. 10: 326-333.

2. Lowe SW, Lin AW (2001) Apoptosis in cancer. Carcinogenesis 21: 485-495.

3. Stenner-Liewen F, Reed JC (2003) Apoptosis and cancer: basic mechanisms and therapeutic opportunities in the postgenomic era. Cancer Res. 63: 263-268.

4. Johnstone RW, Ruefli AA, Lowe SW (2002) Apoptosis: a link between cancer genetics and chemotherapy. Cell 108: 153-164.
5. Wong WW, Dimitroulakos J, Minden MD, Penn LZ (2002) HMG-CoA reductase inhibitors and the malignant cell: the statin family of drugs as triggers of tumorspecific apoptosis. Leukemia 16: 508-519.

6. Graaf MR, Richel DJ, van Noorden CJ, Guchelaar HJ (2004) Effects of statins and farnesyltransferase inhibitors on the development and progression of cancer. Cancer Treat. Rev. 30: 609-641.

7. Aznar S, Lacal JC (2001) Rho signals to cell growth and apoptosis. Cancer Lett. 165: 1-10.

8. Coleman ML, Olson MF (2002) Rho GTPase signaling pathways in the morphological changes associated with apoptosis. Cell. Death Differ. 9: 493-504.

9. Fritz G, Just I, Kaina B (1999) Rho GTPases are over-expressed in human tumors. Int. J. Cancer 81: 682-687.

10. Yamaguchi A, Komori T, Suda $T$ (2000) Regulation of osteoblast differentiation mediated by bone morphogenetic proteins, hedgehogs, and Cbfa1. Endocr. Rev. 21: 393-411.

11. Lian JB, Javed A, Zaidi SK, Lengner C, Montecino M, van Wijnen AJ, Stein JL, Stein GS (2004) Regulatory controls for osteoblast growth and differentiation: role of Runx/Cbfa/AML factors. Crit. Rev. Eukaryot. Gene Expr. 14: 1-41.

12. Karsenty G, Wagner EF (2002) Reaching a genetic and molecular understanding of skeletal development. Dev. Cell. 2: 389-406.

13. Drissi $H$, Hushka D, Aslam F, Nguyen K, Buffone $E$, Koff $A$, van Wijnen $A$, Lian JB, Stein JL, Stein GS (1999) The cell cycle regulator p27kip1 contributes to growth and differentiation of osteoblasts. Cancer Res. 59: 3705-3711.

14. Pratap J, Galindo M, Zaidi SK, Nguyen Q, Buffone E, Koff A, van Wijnen A, Lian $\mathrm{JB}$, Stein JL, Stein GS (2003) Cell growth regulatory role of Runx2 during proliferative expansion of preosteoblasts. Cancer Res. 63: 5357-5362.

15. Hopyan S, Gokgoz N, Bell RS, Andrulis IL, Alman BA, Wunder JS (1999) Expression of osteocalcin and its transcriptional regulators core-binding factor alpha 1 and MSX2 in osteoid-forming tumours. J. Orthop. Res. 17: 633-638.

16. Thomas DM, Johnson SA, Sims NA, Trivett MK, Slavin JL, Rubin BP, Waring P, McArthur GA, Walkley CR, Holloway AJ, Diyagama D, Grim JE, Clurman BE, Bowtell DD, Lee JS, Gutierrez GM, Piscopo DM, Carty SA, Hinds PW (2004) Terminal osteoblast differentiation, mediated by runx2 and p27KIP1, is disrupted in osteosarcoma. J. Cell Biol. 167: 925-934.

17. Galindo M, Pratap J, Young DW, Hovhannisyan H, Im HJ, Choi JY, Lian JB, Stein JL, Stein GS, van Wijnen AJ (2005) The bone-specific expression of RUNX2 oscillates during the cell cycle to support a $\mathrm{G} 1$ related anti-proliferative function in osteoblasts. J. Biol. Chem. 280: 20274-20285.

18. Haÿ E, Lemonnier J, Fromigué O, Guenou H, Marie PJ (2004) Bone morphogenetic protein receptor IB signaling mediates apoptosis independently of differentiation in osteoblastic cells. J. Biol. Chem. 279: 1650-1658.

19. Mundy G, Garrett R, Harris S, Chan J, Chen D, Rossini G, Boyce B, Zhao M, Gutierrez $G$ (1999) Stimulation of bone formation in vitro and in rodents by statins. Science 286: 1946-1949.

20. Sugiyama M, Kodama T, Konishi K, Abe K, Asami S, Oikawa S (2000) Compactin and simvastatin, but not pravastatin, induce bone morphogenetic protein-2 in human osteosarcoma cells. Biochem. Biophys. Res. Commun. 271: 688-692.

21. Li X, Cui Q, Kao C, Wang GJ, Balian G (2003) Lovastatin inhibits adipogenic and stimulates osteogenic differentiation by suppressing PPAR gamma2 and increasing Cbfa1/Runx2 expression in bone marrow mesenchymal cell cultures. Bone 33: 652-659.

22. Rochet N, Dubousset J, Mazeau C, Zanghellini E, Farges MF, de Novion HS, Chompret A, Delpech B, Cattan N, Frenay M, Gioanni J (1999) Establishment, characterisation and partial cytokine expression profile of a new human osteosarcoma cell line (CAL 72). Int. J. Cancer 82: 282-285.

23. McMahon JA, Takada S, Zimmerman LB, Fan CM, Harland RM, McMahon AP (1998) Noggin-mediated antagonism of BMP signaling is required for growth and patterning of the neural tube and somite. Genes Dev. 12: 1438-1452.

24. Domina AM, Smith JH, Craig RW (2000) Myeloid cell leukemia 1 is phosphorylated through two distinct pathways, one associated with extracellular signal-regulated kinase activation and the other with G2/M accumulation or protein phosphatase 1/2A inhibition. J. Biol. Chem. 275: 21688-21694.

25. Deng X, Ruvolo P, Carr B, May Jr WS (2000) Survival function of ERK1/2 as IL-3-activated, staurosporine-resistant Bcl2 kinases. Proc. Natl. Acad. Sci. U.S.A. $97: 1578-1583$

26. Assoian RK (2004) Stopping and going with p27kip1. Dev Cell. 6: 458-459.

27. Wong WW, Tan MM, Xia Z, Dimitroulakos J, Minden MD, Penn LZ (2001) Cerivastatin triggers tumor-specific apoptosis with higher efficacy than lovastatin. Clin. Cancer Res. 7: 2067-2075. 
28. Li X, Liu L, Tupper JC, Bannerman DD, Winn RK, Sebti SM, Hamilton AD, Harlan JM. (2002) Inhibition of protein geranylgeranylation and RhoA/RhoA kinase pathway induces apoptosis in human endothelial cells. J. Biol. Chem. 277: 15309-15316.

29. Werner M, Sacher J, Hohenegger M (2004) Mutual amplification of apoptosis by statin-induced mitochondrial stress and doxorubicin toxicity in human rhabdomyosarcoma cells. Br. J. Pharmacol. 143: 715-724.

30. Cao Y, Zhou Z, de Crombrugghe B, Nakashima K, Guan H, Duan X, Jia SF, Kleinerman ES (2005) Osterix, a transcription factor for osteoblast differentiation, mediates antitumor activity in murine osteosarcoma. Cancer Res. 65: 1124-1128.

31. Rogers MJ (2003) New insights into the molecular mechanisms of action of bisphosphonates. Curr. Pharm. Des. 9: 2643-2658.

32. Lomri A, Lemonnier J, Delannoy P, Marie PJ (2001) Increased expression of protein kinase $C$ alpha, interleukin-1alpha, and RhoA guanosine $5^{\prime}$ triphosphatase in osteoblasts expressing the Ser252Trp fibroblast growth factor 2 receptor Apert mutation: identification by analysis of complementary DNA microarray. J. Bone Miner. Res. 16: 705-712.

33. McBeath R, Pirone DM, Nelson CM, Bhadriraju K, Chen CS (2004) Cell shape, cytoskeletal tension, and RhoA regulate stem cell lineage commitment. Dev. Cell. 6: 483-495.
34. Sahai E, Marshall CJ (2002) RHO-GTPases and cancer. Nat. Rev. Cancer 2 . 133-142.

35. Umansky V, Schirrmacher V (2001) Nitric oxide-induced apoptosis in tumor cells. Adv. Cancer Res. 82: 107-131.

36. Armour KJ, Armour KE, van't Hof RJ, Reid DM, Wei XQ, Liew FY, Ralston SH (2001) Activation of the inducible nitric oxide synthase pathway contributes to inflammation-induced osteoporosis by suppressing bone formation and causing osteoblast apoptosis. Arthritis Rheum. 44: 2790-2796.

37. Altieri DC (2003) Survivin, versatile modulation of cell division and apoptosis in cancer. Oncogene 22: 8581-8589.

38. Blanco-Colio LM, Villa A, Ortego M, Hernandez-Presa MA, Pascual A, Plaza JJ, Egido J (2002) 3-Hydroxy-3-methyl-glutaryl coenzyme A reductase inhibitors, atorvastatin andsimvastatin, induce apoptosis of vascular smooth muscle cells by downregulation of $\mathrm{Bcl}-2$ expression and Rho A prenylation. Atherosclerosis 161: 17-26.

39. Kawata S, Yamasaki E, Nagase T, Inui $Y$, Ito N, Matsuda $Y$, Inada M, Tamura S, Noda S, Imai Y, Matsuzawa Y (2001) Effect of pravastatin on survival in patients with advanced hepatocellular carcinoma. A randomized controlled trial. Br. J. Cancer 84: 886-891.

40. Fromigué O, Lagneaux L, Body JJ (2000) Bisphosphonates induce breast cancer cell death in vitro. J. Bone Miner. Res. 15: 2211-2221. 